\title{
The Feasibility of Punishment and the Credibility of Threats: Case Studies on the First Moroccan and the Rhineland Crises
}

\author{
Yang Gyu Kim
}

To what extent can high resolve compensate for relatively low capability, and vice versa? This article aims to contribute to the literature on coercive use of force by reintroducing a neglected but significantly important variable, the feasibility of punishment. As military and political feasibility to follow through on the threat is a necessary condition for making a credible threat, threat strategy should fail however resolved the threatener may be if the feasibility of punishment is low. Process-tracing is applied to test this feasibility hypothesis against cases of the 1905 First Moroccan Crisis and the 1936 Rhineland Crisis.

Key Words: credibility, feasibility, deterrence, compellence, the First Moroccan Crisis, the Rhineland Crisis

\footnotetext{
* Yang Gyu Kim is a Visiting Scholar at Arnold A. Saltzman Institute of War and Peace Studies at Columbia University and an Adjunct Professor in the Department of Politics and International Relations at Florida International University (FIU). He holds a Ph.D. in International Relations from FIU (2019). He is currently researching the significance of conventional capabilities for predicting the outcome of international crises involving nuclear powers and small powers' strategies of deterring stronger adversaries. ORCID ID: https://orcid.org/0000-0002-9684-1538

This work was supported by the World Politics and Statecraft Fellowship of the Smith Richardson Foundation (Grant \#2019-1914) and the Dissertation Year Fellowship of University Graduate School at FIU. The author is grateful for the constructive comments of the three anonymous reviewers, and thank Robert Jervis, Félix E. Martín, Terrence G. Peterson, Erin Damman, and Roseanne McManus for their helpful comments on earlier drafts of this article.
} 


\section{INTRODUCTION}

Cases of threat strategy abound in human history. ${ }^{1}$ In international relations, we have witnessed that coercive use of force, or threat of using military power to punish the adversary for its non-compliance, is much more common than its physical use (Art 1996, 7-42). This is because of the "information problem," states can feign their capability and resolve and induce capitulation without incurring much cost (Fearon 1995, 395-401; Powell 1999, 9; Carlson 1998, 226-227).

This does not mean that threat strategy has been effective. In fact, out of 58 attempts of "extended deterrence," 24 deterrent threats (about 41 percent) have failed in history (Huth and Russett 1988, 31-33). Likewise, coercive diplomacy shows a mere 32 percent success rate (Art and Cronin 2004, 403). Accordingly, since the seminal publication of Thomas Schelling's books on coercive diplomacy (Schelling 1960; 1966), the literature on international crises has focused on formulating hypotheses to suggest diverse ways to enhance the chances for successful coercion. ${ }^{3}$

The literature, however, has not reached a consensus on various issues, including: Should we study and analyze threats for dissuasion (deterrence) and persuasion (compellence) separately? How can we address the fundamental problem of researching non-events in deterrence situations? Which is more critical for the success of threat strategy, capability, or resolve? keeping these issues in mind, this article aims to contribute to the literature by introducing a neglected but important variable, the feasibility of punishment. As specified later, military and political feasibility to follow through on threat is one aspect of capability and a necessary condition for making a credible threat. Lacking it, thus, most likely leads to non-believability of threat and subsequently to failure of coercion. Therefore, when the feasibility of punishment is low, threat strategy is likely to fail, however resolved the threatener may be.

This article first discusses unsolved problems in the literature on threat strategy. Then, it points out that the feasibility of punishment variable has been downplayed in the literature despite its significant impact on deterrence/

\footnotetext{
${ }^{1}$ This article uses the term "threat strategy" to indicate the coercive use of force for both persuasion and dissuasion as explained in the second section.

${ }^{2}$ The deterrence literature categorizes deterrence cases according to four ideal types: "direct deterrence," "extended deterrence," "general deterrence," and "immediate deterrence" (Huth 1999, 27).

${ }^{3}$ A few recent examples include: George and Simons (1994); Fearon (1994a, 577-92;1994b, 6890); Freedman (1998); Huth (1997, 72-99); Zagare and Kilogue (2000); Danilovic (2002); Morgan (2003); Slantchev (2011); Sechser and Fuhrmann (2017); McManus (2017).
} 
compellence failure and suggests a new causal model based on feasibility. The third section tests rival and research hypotheses formulated based on the alternative causal model against two cases: the 1905 First Moroccan Crisis and the 1936 Rhineland crisis. Process-tracing is applied to identify critical variables that prompted policymakers in Paris and Berlin to believe or disbelieve their opponents' threats. Lastly, a concluding section discusses the implications and limitations of the findings.

\section{UNRESOLVED ISSUES IN THE LITERATURE ON COERCIVE DIPLOMACY}

\section{Deterrence vs. Compellence}

Since its introduction, the term coercion has suffered from conceptual ambiguity. While some scholars define it as the use of threat for persuasion and dissuasion (Schelling 1966; Sperandei 2006, 253-80), others use it to indicate only forceful persuasion (George and Simons 1994; Pape 1996; Art and Cronin 2004; Sechser and Fuhrmann 2017). Schelling defines deterrence as a threat intended to "keep [the opponent] from starting something" and compellence as a threat aiming to "make an adversary do something" (Schelling 1966, 69, 71-84). Except for David Baldwin, who argues that deterrence and compellence are semantically indistinguishable (Baldwin 1979, 188), most scholars agree that the two are analytically distinct strategic policies.

However, the demarcation line between these two policies is empirically difficult to establish. A classic example is a threat made after "general deterrence" failure. If the defender attempts to articulate another threat ("immediate deterrent threat") (Morgan 1977, 28) after the failure to avoid further deterioration of the crisis, this threat carries both deterrent and compellent elements. It is still a deterrent attempt as the defender tries to prevent additional aggressive defiance by the challenger. However, it is a compellent threat, too, because the challenger would intuit at this juncture that the status quo shifted in its favor while the defender demands the challenger to renounce what is already accomplished. This explains why scholars code the same threats differently. Some identify them as deterrence cases, while others define them as acts of compellence(Lebow and Stein 1990, 338-339).

This study takes a pragmatic approach in addressing this issue: I use the term threat strategy to indicate "psychological and non-violent use of military force for both dissuasion and persuasion." This approach is justified by the fact that 
deterrence and compellence theories suggest very similar variables for explaining the success of each strategy, as described further in the following section. It implies that the causal mechanism for successful deterrence and compellence is quite similar. Therefore, integrating the two sub-types of coercion into a single strategy of threat should not raise severe problems if the goal is to establish a causal model for its success or failure.

\section{The Problem of Studying Non-Events in Deterrence}

Deterrence studies particularly face a significant challenge in studying non-events and identifying the population of general deterrence success. Cases of compellence success are easily defined because the threatener is the challenger and initiator of the crisis. However, in a situation of deterrence, the threatener is the defender waiting indefinitely for the challenger to defy the former's threat. In this context, the preservation of stability cannot always be attributed to deterrence success as potential challengers might decide to refrain from disrupting the status quo for reasons independent of the deterrent threat (Harvey 1997, 33). This poses severe challenges to the validity of deterrence research as it could lead to "false negatives" (excluding actual cases of deterrence success) or "false positives" (including spurious success cases) (Huth and Russett 1993, 62).

Deterrence dynamics, thus, are only observable in the aftermath of its failure. The "third wave" of the deterrence literature (Jervis 1979, 302) attempted to address this difficulty by inferring conditions for general deterrence success from those for immediate deterrence (Huth 1999, 27). However, the "selection effect" (Fearon 2002, 5-29) reveals that causal effects of independent variables derived from general deterrence cases cannot be expected to bring out the same result in immediate deterrence situations. There have been efforts to solve this problem by turning to "enduring rivalries" (Huth and Russett 1993), "politically active dyads" (Quackenbush 2006, 37-51), and "sample of defense pacts" (Johnson, Leeds, and Wu 2015, 309-36). As they recognize, however, even these creative methods cannot entirely fix the problem.

One possible solution to this problem that no previous studies have tried is to analyze only the deterrence failure cases. Although this approach does not help us much in resolving the problem of "false negatives," it addresses the problem of "false positives." Yet, this method introduces a new challenge: the dependent variable does not vary. The sample only includes cases of the adversaries' policy choice of non-compliance with the defender's threat. ${ }^{4}$ We can address the issue of the non-varying dependent variable by changing the unit of analysis from states to decision-makers. It is unlikely that all policymakers support a strategy 
of challenge against the deterrer unanimously; we can allow the dependent variable to vary by turning our focus from states' behaviors to government officials' policy positions. Then, a researcher can compare the positions of those policymakers who believe in the deterrent threat with those who do not and trace which factors cause them to have different conclusions.

\section{Conditions for Success: Capability vs. Resolve}

Given the high failure rate of threat strategy, the central question in the literature, which this article also tries to answer, is "What makes a threat credible and effective?" The compellence literature has not formulated a systematic causal model for compellence success because each compellent threat involves specific demands and assurances, making it challenging to generalize the results (George and Simons 1994, 268). Different studies provide divergent lists of variables for compellence success. The most comprehensive list, however, includes eight conditions: (1) clarity of the object, (2) strength of motivation, (3) asymmetry of motivation, (4) sense of urgency, (5) strong leadership, (6) adequate domestic and international support, (7) unacceptability of threatened escalation, and (8) clarity concerning the precise terms of crisis settlement (George and Simons 1994, 279-287). Others tend to emphasize the significance of one or two factors among the eight rather than suggesting new variables (Schaub 1988, 46-57; Art and Cronin 2004, 372; Sechser and Fuhrmann 2017, 30-34).

On the other hand, deterrence studies suggest three standardized models for deterrence success: "Classical Rational Deterrence," "Costly Signaling," and "Inherent Credibility" (Danilovic 2002, 9-21). First, the Classical Rational Deterrence model (Orme 1987, 96-124; Huth and Russett 1988; 1990, 466-501; Harvey 1999, 840-871) argues that deterrence fails due to not meeting one or more of the four prerequisites: (1) clear definition of undesirable behavior, (2) explicit commitment and signaling, (3) capability to defend commitment and (4) resolve to implement punishment in case adversaries fail to comply. While some scholars argue that deterrence can fail by not satisfying a single element among the four (Orme 1987; Harvey 1999), others emphasize that a deterrent threat would most likely succeed when it is considered credible by the target state (Huth and Russett

\footnotetext{
4 This approach also can lead to selection bias by choosing only those instances of deterrence failure where the challengers are most likely determined ones. If the deterrent threat failed because the challenger was determined to revise the status quo no matter what the defender did, the case does not help in identifying conditions for deterrence success. However, if the study could demonstrate that the challenger was not particularly determined through careful review of the archive, as this article attempts to do, the result would still have meaningful implications for the deterrence literature.
} 
1990; Huth 1999). This threat credibility is secured "if the defender possesses the military capabilities to inflict substantial costs on a challenger in armed conflict and if the challenger believes that the defender is resolved to use its available military forces" (Huth 1999, 29).

Second, the Costly Signaling model (Schelling 1966; Fearon 1994; Zagare and Kilgour 2000; Slantchev 2011) criticizes the classical model for conflating two completely separate issues - capability and credibility - and subsequently has caused much confusion. Scholars in this camp argue that capability and credibility are two very different concepts that need to be analyzed separately (Quackenbush 2011, 761). Frank Zagare and Marc Kilgour point out that credibility is an issue of rationality. a state's preference for executing threats over backing down. Capability, however, is a matter of physical ability (1) to execute the threat and (2) to inflict enough pain to make the target state change its preference order when the threat is executed. Numerous researchers made mistake conflating these two separate concepts by failing to distinguish between "unwillingness" and "being unable to do something." Threats, thus, "can be credible without necessarily being capable" (Zagare and Kilgour 2000, 65-84).

In this context, threat credibility is defined by calculating the expected utility of imposing punishment, and the "tying hands" strategy is conducive to deterrence success. This strategy seeks to create costs that "would be paid ex post" if the defender fails to follow through on its threats (Fearon 1997, 82) and to increase "the expected payoff from war relative to the expected payoff from capitulation" (Slantchev 2011, 47). A deterrent threat, thus, would seem believable when the interest at stake is high, the probability of victory in war is high, war cost is low, and audience/reputation cost for backing down from the threat is high for the defender.

However, the third model, the Inherent Credibilitymodel (George and Smoke 1974; Danilovic 2002), expresses doubt about the relevance of tying hands strategy in deterrence success. If the interest at stake is low for the defender, any manipulation tactics, however sophisticated they may be, would not help its deterrent threat be believable. Vesna Danilovic claims that "the national interest, shaping the inherent credibility of threats, sets the limits to the impact of the other two factors on the opponent, i.e., a deterrer's capacity to carry out its threat and manipulative strategies it uses to communicate a strong resolve" (Danilovic 2002, 4-5). Therefore, there is no way to enhance the credibility of a deterrent threat if it is to protect low interest at stake.

In sum, given that the threat is clearly defined and communicated, five variables are emphasized in the literature for deterrence success: "military capability," the "probability of victory" in case of war, "interest at stake," "war 
cost," and "audience cost" for backing down. Although studies on compellence do not have a consensus on the variables conducive to compellence success, most agree on the significance of "relative military capability" and "balance of interest."

Yet, this list of independent variables for deterrence/compellence success still has some issues. First, previous works do not consider the element of emotion and logic of vengeance seriously. In the nuclear era, in which nuclear retaliation and mutual destruction are totally irrational, deterrence can be only credible when it is based on a "human drive for revenge" that overrides the cost-benefit analysis (McDermott, Lopez, and Hatemi 2017, 69-88). Second, the Costly Signaling and Inherent Credibility models define credibility solely based on the degree of resolve, and fails to reflect fully the fact that it is a necessary condition for the success of threat strategy that the threatener secures offensive capability or "power to hurt" (Schelling 1966, 3) that could damage its opponent enormously. Third, although the Classical Rational Deterrence model and the compellence literature acknowledges the significance of capability, they do not try to answer questions such as, "Which should matter more for deterrence/compellence success, capability or resolve?" or "To what extent can high resolve compensate for relatively low capability, and vice versa?” This article seeks to address these shortcomings by suggesting a new model for deterrence/compellence success.

\section{A NEW MODEL: THE NON-FEASIBILITY OF PUNISHMENT AND THE FAILURE OF THREAT STRATEGY}

\section{The Feasibility Model: Strong Resolve Cannot Compensate for Low Feasibility}

The below figure summarizes all the variables discussed in the previous section regarding the elements that decide the level of threat credibility.

As the figure shows, the deterrence/compellence literature has mainly focused on identifying factors that decide the resolve aspect of credibility. Even Zagare and Kilgour who suggest a rigorous conceptual framework that allows us to notice the existence of the two distinct realms within the capability variable, do not examine further the causal impact of these capability variables as if they were uninteresting or unimportant (McManus 2017, 23). Moreover, subsequent studies in the deterrence/compellence literature have not discussed the "ability to execute the threat" variable either.

However, if Zagare and Kilgour are right and "a capable threat is a necessary 
Figure 1. Elements of Threat Credibility

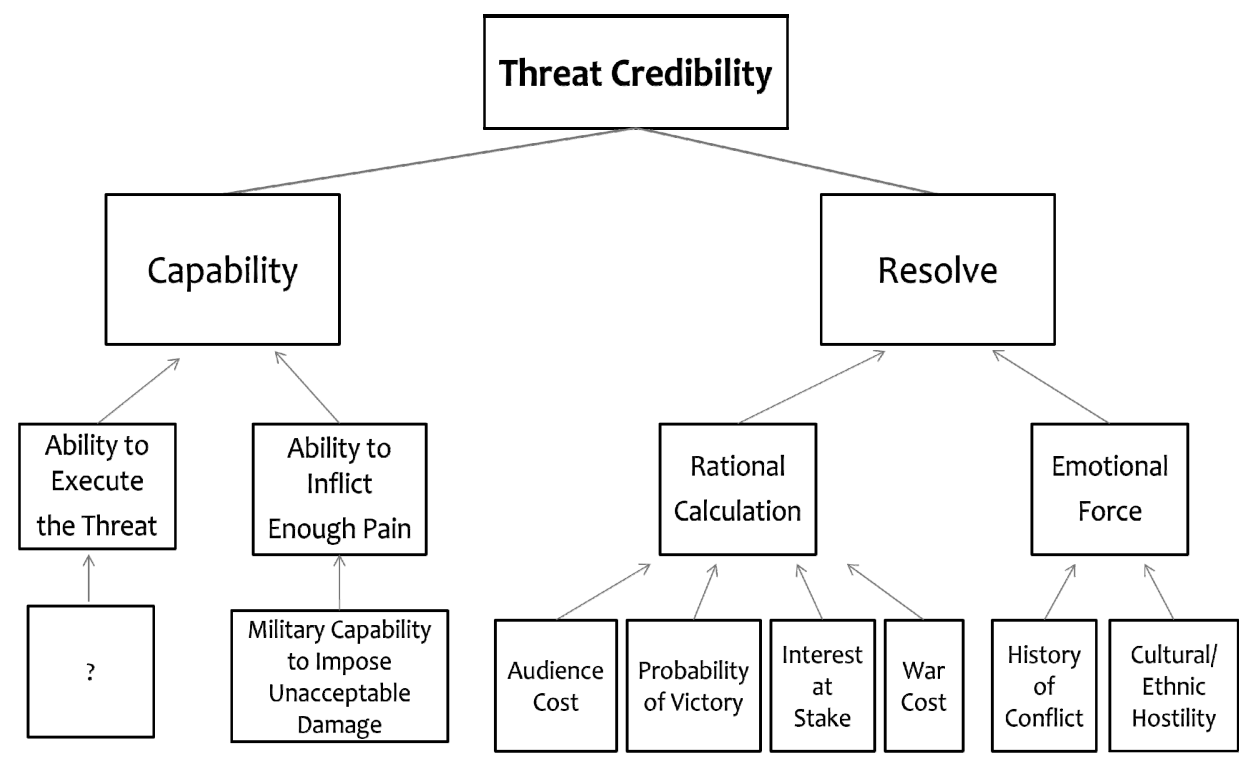

condition for general deterrence stability" (Zagare and Kilgour 2000, 81), lacking any elements in the capability aspect of threat credibility will surely lead to the failure of threat strategy. Although most academic works in coercive diplomacy zero in on identifying sufficient conditions for deterrence and compellence success, necessary conditions for it are as much important as the sufficient ones given that the absence of the former always brings failure of the strategy. Therefore, identifying the necessary conditions for the success of coercive diplomacy can help us to develop a parsimonious model for explaining its failure.

For example, even when the threatener possesses the "ability to inflict enough pain" and strong resolve to punish the opponent (supported by both "rational calculation" and "emotional force"), the degree of its credibility should go down to zero if the threatener lacks the "ability to execute the threat." In analogy, this is similar to the situation when a robber or a police officer, who suffers from a fractured index finger and, thus, is physically incapable of pulling the trigger, points a gun at a person and screams menacingly: "Give me your wallet!" or "Freeze!" If the receiver knows this condition, then his threat would be incredible regardless of his aggressive intention and destructive power.

This analogy attests that lacking the capability to pull the trigger (or execute/ follow through on a threat) is a sufficient condition for the failure of a threat 
strategy. This capability to execute a threat has two dimensions. First, the threatener should maintain military capability to reach the opponent's territory and deliver the offensive power to inflict described costs. Second, it must also have the political ability to implement punitive measures against opponents, overcoming possible opposition from domestic political factions or international audiences. Securing both military and political capabilities is the threshold of making a credible threat.

Roseanne McManus's work is the sole exception in the literature that pays attention to this causal mechanism. She acknowledges this loophole in the literature and emphasizes the need for developing a better understanding of "what the ability to follow through consists of and how various observable factors can influence it." McManus defines the ability to follow through on statements of resolve as the "absence of major obstacles and unacceptable risks." relevant factors include (1) military strength, (2) hawkish domestic veto players that would not stand in the leader's way to execute threats, and (3) security in office (McManus 2017, 22-42).

Although McManus suggests a helpful model to fill the literature gap, her work presents some limitations. First, since she tests her model only against a single crisis actor, the United States, the observable factors used in her research (especially variables of "hawkish veto players" and "security in office") are not designed for analyzing cases of authoritarian regimes. We need more relaxed indicators for measuring the threatener's political feasibility to punish given that there are various types of political regimes besides representative democracy like the U.S. Second, her way of using the military capability variable is not specified enough to be tested against other deterrence/compellence models. Military strength could have an impact on (1) the ability to inflict an enormous cost on the challenger, (2) probability of victory in war, and (3) war cost. Notably, the last two are essential factors in the Costly Signalling model for calculating the rationality of punishing the adversary. In order to establish a new model that can compete with other models suggested in the literature, we need to define military feasibility more precisely.

In this context, this article aims to develop McManus's causal model and demonstrates that even the most resolved threatener's threat would be considered non-credible if it is infeasible for the deterrer/compeller to implement the asseverated punishment. It is when: first, the defender lacks power projection capabilities to overcome geographic obstacles (i.e., oceans, large rivers, and mountains) that exist between the defender and its potential challengers, and the challenger's defensive capability that could neutralize the defender's punitive offense; and, second, the defender faces strong 
domestic/international political oppositions such as dovish veto players, low approval ratings, severe and chronic anti-government demonstrations, or unsupportive alliance partners that could delay or even frustrate policy implementation.

If the threatener fails to secure these military and political feasibilities, he would be unable to pull the trigger and punish the opponent's non-compliance. When the adversary realizes that the threatener's forefinger is fractured, he would not believe that the latter will be able to stand firm against the former's challenge despite his destructive capability and firm resolve to defend the interest at stake. Failures of nuclear deterrence/compellence in the 1973 Yom Kippur War, 1982 Falkland War, 1990 Gulf War, and 2001 Afghanistan and Iraq Wars illustrate how threat strategy can fail despite the significance of the interest at stake (i.e., sovereignty, territorial integrity, or national security of the threatener or its allies) for the deterrer/compeller and enormity of the destructive power (nuclear weapons) the threatener possesses.

\section{Research Hypotheses}

This article takes a similar view on the standard model of deterrence/ compellence success: making a crediblethreat is nearly a sufficient condition for the success of the threat strategy. Granted, if the adversary is highly resolved and seeking merely a casus belli, making a credible threat would only lead to war (Lebow 1987, 211). Yet, this condition of an extremely resolved enemy is difficult to satisfy in international crises except for the case of its national survival. In most cases, crisis actors have limited aims. Making a credible threat, thus, would most likely cause the target state not to escalate the crisis.

Then, what matters most in the study of coercion is determining factors that lead to high credibility of threats. Thus, the dependent variable for this research is threat credibility. As discussed above, recent deterrence/ compellence literature underlines the significant impact of resolvein deciding the credibility of threats. A threatener is resolved when: (1) cost-benefit analysis supports carrying out the threat (i.e., the interest at stake is high; the probability of victory is high; the war cost is low, or the audience cost for backing down is high); or (2) the level of antagonism between the threatener and its adversary is high (i.e., the existence of serious war/conflict history or cultural/ethnic hostility) and it defeats or distorts the standard cost-benefit analysis by making it feel so good to retaliate against the opponent no matter how devastating the cost As long as the adversary's policymakers perceive that the threatener is resolved, they would most likely believe the threat. This expectation formulates the rival hypothesis that this research tries to compete with. 
Rival Hypothesis: If the adversary's decision-makers perceive the threatener is resolved to punish against their non-compliance with the threat, then the adversary will likely believe the threat.

On the other hand, this article suggests an alternative causal path for threat credibility. As explained earlier, irrespective of the level of resolve the threatener maintains, a threat is not credible if it is infeasible for the threatener to implement the threat. The feasibility of punishment is "a crisis actor's ability to implement the policy of punishment." It is one aspect of capability and different from the willingness to honor the commitments. The feasibility of punishment includes two aspects: military feasibility and political feasibility. military feasibility is measured by whether the threatener secures the capability to project its offensive power to hurt the challenger. It includes factors such as offensive platforms (i.e., rapid deployment force, strategic bombers, ballistic missiles, and aircraft carriers), relevant doctrines to operate the offensive mission, and military readiness. political feasibility indicates the threatener regime's political capability to execute security policies despite domestic (i.e., divided government, low approval rates, etc.) and international political oppositions (i.e., tensions between allies, patron's buck-passing strategy, etc.). Accordingly, a threat is infeasible when the threatener lacks power projection capability or if it faces strong internal and external political opposition to the government's foreign policy execution. High resolve, thus, does not compensate for low feasibility in this model.

Research Hypothesis: If the adversary's decision-makers account that the threatener lacks the militaryand political feasibility to punish them for their non-compliance, then the adversary will be unlikely to believe the threat.

\section{CASE STUDIES OF THE FIRST MOROCCAN AND THE RHINELAND CRISES}

The 1905 First Moroccan Crisis and the 1936 Rhineland Crisis serve as empirical cases to test the validity of the rival and research hypotheses expounded above. This study selects these cases because, first, the First Moroccan Crisis is a compellence encounter, and the 1936 Rhineland Crisis is a deterrent confrontation between France and Germany. The variety of case dynamics enhances the analysis of threat strategy. Germany was the challenger, and France 
was the defender in both cases. However, whereas the threatener was Germany (compeller) in the Moroccan case, it was France that employed the threat strategy (deterrence) in the Rhineland Crisis. Second, these cases occurred more than half a century ago, and most of the relevant primary sources are declassified and available. 5 Abundant data makes it easy for a researcher to open the black box of decision-making and trace the rationale behind each policy choice.

Third, they were hard cases for compellence success and deterrence failure because the balance of interest favored Paris in both cases. It was difficult to believe the German threat of war in the First Moroccan Crisis as Morocco was much more important to Paris than Berlin. On the contrary, the French deterrent threat was hardly non-credible given that the Rhineland regime was the crux of the Treaties of Versailles and Locarno and the backbone of her national security system. Yet, Germany's compellence threat succeeded in the Moroccan Crisis while the French deterrence failed in the Rhineland. Both cases, thus, are an interesting anomaly for standard deterrence/compellence models.

The selection, however, is not without limitations. First, not only is the number of observations small, but it is difficult to prove that these two cases are representative enough to systemically reflect the average value of the population involving the threat strategy. Second, it is not impossible to assume that policymakers in both Paris and Berlin were all educated, discreet, and rational, and, thus, very similar. However, this does not guarantee that they are similar enough to allow for "most-similar comparative design" (Seawright and Gerring $2008,304)$ to be applied for analysis especially considering the significant dissimilarities of the two countries (e.g., regime type, strategic culture, and interpretation of the history). Therefore, the case studies should function as empirical testing grounds for "falsification" rather than "verification" (Popper 1968). In other words, surviving the empirical test does not prove the theory, while failing it rejects its validity.

The unit of analysis is policymakers rather than the state, not only for increasing the number of observations but also to overcome the aforementioned problem in selecting deterrence failure cases. Process tracing is used to observe the causal paths of crucial variables and check whether and how they move as predicted by the hypotheses. The method usually works as a "method of elimination" (Collier 2011, 827) and tries to eliminate as many rival explanations as possible by turning to four different tests: "straw-in-the-wind," "hoop,"

${ }^{5}$ This paper mainly turns to Documents diplomatiques français (hereafter DDF), 1871-1914, $2 \mathrm{e}$ Série, Tome IX.; Documents on German Foreign Policy (hereafter DGFP), 1918-1945, Series C, Vols. IV-V; and Trial of the Major War Criminals before the International Military Tribunal (hereafter TMWC), X-XX. 
"smoking gun," and "doubly decisive."6 These tests mainly involve examining the truth of hypotheses using set theory (Mahoney, Kimball, and Koivu 2009).

\section{The First Moroccan Crisis: Delcassé's Disbelief vs. Rouvier's Belief in the Credibility of Germany's Compellent Threat}

Under the leadership of Foreign Minister Théophile Delcassé, France sought its dominance over Morocco in the late 1890s. The primary motivation behind this policy was to restore the desirable power equilibrium in Europe that had been disrupted by the rapid rise of Germany (Anderson 1930, 7; Williamson 1969, 30-31). Consecutive French rapprochements with Italy and Spain in the late 1890s and the early 1900s and the establishment of the Entente Cordiale in April 1904 should be understood in this context. Delcassé tried to isolate Germany throughout this diplomatic expedition over the Moroccan problem.

Berlin realized that a dangerous anti-German coalition was evolving (Fischer 1975, 55). Specifically, the French-Italian Entente would have, in effect, nullified the Triple Alliance (Germany, Austria-Hungary, and Italy) in case of a Franco-German war (Anderson 1930, 144). These alarming changes needed to be addressed immediately. Therefore, starting from Kaiser Wilhelm II's surprise visit to the city of Tangier on March 31, 1905, where he supported the independence of Morocco, Germany demanded France to hold an international conference to discuss this matter. Berlin believed that it might be possible to reveal London's lukewarm support for the Entente through this conference and subsequently sway the germinating bond between Britain and France.

Delcassé opposed any international conference over Morocco. Berlin increased the pressure by demanding the opening of a conference and the resignation of Delcassé. In April 1905, the threat was indirect and implicit (Williamson 1969, 32; Anderson 1930, 217; 222). By June 1905, Germany made it clear that France was dealing with a resentful opponent ready to initiate war if its demands were not accepted (Anderson 1930, 225; 230). On June 4, targeting

\footnotetext{
${ }^{6}$ First, passing the "straw in the wind" test implies that the hypothesis is relevant to explain the phenomenon but it is neither necessary nor sufficient to establish causation with the variable. Second, the "hoop" test is related to necessary but not sufficient condition for causation. Passing this test affirms the relevance of the variable in causal mechanism but does not confirm the hypothesis. Failing to pass this test, however, leads to rejection of the explanation/hypothesis. Third, the "smoking gun" test is for identifying sufficient but not necessary condition: the factor is indeed the cause for that phenomenon but there might be other variables that can explain this. Passing this test confirms the hypothesis but failing to do so does not result in the elimination of the hypothesis. Lastly, passing the "doubly decisive" test indicates that the variable is both a necessary and sufficient condition for causation: the factor is the cause and it is impossible to explain the event without it. It is quite rare to find evidence that can pass the doubly decisive test in social science (Bennett 2010, 210-211).
} 
the French cabinet meeting, German Chancellor Bernhard von Bülow explicitly threatened Paris with a war (Herrmann 1996, 40).

Meanwhile, as tensions increased, London made every effort to assure France. It delivered an aide-mémoire on April 25, 1905, that promised to give "all the support in its power" against Germany (Anderson 1930, 210-211). Nonetheless, Paris fell into a panic. At the Cabinet meeting on June 6, 1905, Delcassé insisted that Germany was bluffing while all the other members, spearheaded by Prime Minister Maurice Rouvier, took German threats seriously (Anderson 1930, 230-232; Williamson 1969, 39-40). Delcassé was forced to resign that day.

Why didn't Delcassé believe the German war threats? According to the memo of the cabinet meeting on June 6, Delcassé's argument can be summarized into three points. First, Britain sent written documents indicating London's interest in developing the Anglo-French Entente to a formal alliance. Second, Germany was bluffing according to intelligence Delcassé gathered from French ambassadors abroad. Third, if France backed down this time, the Entente would fall apart, and London might even side with Berlin (DDF, 2/IX, 602). In other words, his rationale behind the position to resist German demands was: (1) the threat was bluffing; and (2) Paris should resist Berlin's scheme to sabotage the Anglo-French partnership and strengthen the bilateral security partnership.

Delcassé did not clarify the relationship between the two points, whether the second point was dependent on the first or vice versa. It is not clear whether (1) Paris should go ahead and solidify the Entente as Berlin was merely bluffing, (2) Germany was bluffing given the strength of security cooperation between Paris and London, or (3) the two points are independent and not connected. It is impossible to determine which reflects his correct reasoning, especially because Delcassé called Berlin's bluff without specifying the claimed intelligence he gathered from French ambassadors. This attitude of maintaining a certain level of secrecy was typical in the Quai d'Orsay in order to protect the foreign ministry's independence (Clark 2012, 191). At best, thus, we could make an educated guess.

The rival hypothesis predicts that Delcassé did not believe the German threat because the latter did not seem resolved. However, this explanation does not survive the hoop test considering Delcassé's foreign policy basis from 1898 to 1904 (Hayne 1993, 95-115). He maintained the strong anti-German sentiment throughout his career. The Franco-Prussian War broke out in his late teens and left a permanent mark for him. Delcassé was confident that Berlin's Weltpolitik inevitably would lead to a major war in Europe, and this view was prevalent in the Quai d'Orsay (Hayne 1993, 119-122; 128-129). The political elites in the French Foreign Office, thus, were relentlessly pursuing an entente with Britain after securing Russia's support in 1893 to prepare a war against Germany that always 
had possessed relatively superior forces than France. France needed allies to be victorious in war and regain the Alsace-Lorraine (Hayne 1993, 128). Paris's actively seeking a military alliance with first Britain and then Russia to counter the German threat is hoop evidence for Delcassé's confidence that Germany was a determined aggressor and a resolved challenger. As it does not survive the hoop test, the rival hypothesis should be rejected.

Then, how could he believe that Germany was bluffing despite his judgment that Berlin was a revisionist power seeking an opportunity to start a war in Europe? Was this because Berlin lacked military and political feasibility to follow through on the threat as predicted by the research hypothesis? Considering Berlin's autocratic political system that increases the political ability to implement the war threat, shouldn't it be dangerous to discredit its threat? It is quite challenging to explain Delcassé's rationale behind his choice of defying Germany's compellent threat, given that Berlin was a resolved challenger with high political feasibility to implement the punishment.

Eugene N. Anderson argues that it was British support that emboldened Delcassé to withstand German threats (Anderson 1930, 229). He was "most grateful" for the British aide-memoire that underscored London's will to support France "to oppose Germany in the whole Moroccan question" (Anderson 1930, 211). The British commitment to treat Paris with "the most absolute confidence" was iterated on May 17, 1905. The French military and naval officers started to consult with English counterparts right after this (Anderson 1930, 227- 228).

In this context, the possible reason for Delcassé's calling Germany's bluff was either (1) he believed in the absolute superiority of Anglo-Franco combined forces over the German military in war; or (2) that strong British military support would cancel out some of the German power projection capability, which would make Berlin's offensive operations infeasible. It is difficult to find any archival evidence for the first proposition, but there is one for the second.

To illustrate, in April of 1905, the Royal Navy played a series of war games for a possible Franco-German war. The First Sea Lord John Fisher and Captain Sir Charles L. Ottley, the Director of Naval Intelligence, believed that British coastal operations against Germany should constrain the degree of German offense against France in the early stage of the war (Williamson 1969, 44). It is uncertain whether Delcassé was aware of this British plan. Still, the Quai d'Orsay should have expected a similar possibility for them to stand against German threats adamantly and consistently despite their firm belief that Germany was planning to invade France. This fact provides the straw-in-the-wind evidence for the claim that Delcassé discredited the German threat due to the latter's limited power projection capability to follow through. The research hypothesis, thus, is weakly 
supported when tested against Delcassés position.

Then, why did Prime Minister Rouvier decide to concede to Germany despite London's strong commitment to supporting France militarily? In the cabinet meeting on June 6, Rouvier argued that the German war threat is not a bluff considering the serious security challenge Berlin faced: The anti-German coalition that France had created encircled Germany. He believed that Delcassé's project to isolate Germany was equivalent to a declaration of war on Berlin $(D D F$, 2/IX, 602). Rouvier then expressed his four doubts: (1) British motives, (2) the value of British military aid, (3) preparedness of the French Army, and (4) the strategic value of Morocco (Williamson 1969, 39-40).

Anderson explains that Rouvier was a businessman who conducted foreign policy like running a company. He thus "suspected Great Britain of attempting to use France as a cat's-paw against Germany" considering that the British navy "did not have wheels" (Anderson 1930, 212). Besides, the British Army was underequipped and small (Herrmann 1996, 42). The size of the expeditionary force that Britain could send was about 115,000 men. On the contrary, the estimated peacetime size of the French and German armies amounted to 595,000 and 609,552 men, respectively (Herrmann 1996, 41-42). It would even take too much time for the British forces to arrive on time to support decisive battles (Herrmann 1996, 43-44). It seemed evident that France should fight alone during the initial phase of a war against the much superior German army (Herrmann 1996, 45-47). Rouvier acknowledged that the Anglo-French coalition navy would successfully destroy nearly all German ports. During the time, however, the French territory would be invaded and destroyed ( $D D F, 2 / \mathrm{IX}, 602)$.

Rouvier's belief in the credibility of the German threat, thus, was based on the notion that it was not only feasible for Germany to punish France's non-compliance with its threat but also that Berlin was resolved to do so. As France shared a border with Germany, the Kaiser's word should sound quite threatening: "We know the road to Paris, and we will get there again if need be" (Williamson 1969, 32). The threat came directly from an authoritarian leader, not from an elected official who should answer to the constituents. It seemed rational for Germany to initiate a war considering the significant interest at stake as well as the high probability of victory and the manageable level of war cost given that relative military balance was advantageous to Germany even against the British-French combined forces at the initial stage of the war. As a businessman, Rouvier did not share Delcassé's Germanophobia. The lack of emotional impetus did not prevent him from believing the authenticity of German threats. In sum, the German military advantage over Anglo-French coalition forces, at least in the early phase of the war, would make it not only militarily and politically feasible 
for Berlin to punish France but also lead Berlin to be resolved to do so. As his rationale for accepting the credibility of the German threat is explicitly linked to this fact, both rival and research hypotheses survive the smoking gun test when tested against Rouvier's rationale.

\section{The Rhineland Crisis: Hitler's Disbelief vs. Other Policymakers' Belief} in the Credibility of the French Deterrent Threat

The Rhineland regime was established after the Great War to prevent another war. It installed a demilitarized zone that extended fifty kilometers to the East and the West from the Rhine, using the river as a natural barrier against possible invasion from Germany (Schuker 1986, 299-339). This zone made German military advance towards France or the Low Countries very difficult. At the same time, demilitarization left Germany's west flank unprotected. Thus, it allowed France and the Little Entente countries to quickly create a two-front war for Germany (Weinberg 1970, 239).

It is not surprising that Adolf Hitler wanted to restore full sovereignty over the Rhine as soon as he rebuilt German armed forces at an astonishing pace in the early 1930s. By late 1935, Hitler realized that any attempt to demolish the Rhineland regime should be executed promptly because worsening economic conditions precluded Germany from sustaining its rapid rearmament program (Weinberg 1970, 245-6; Kennedy 1989, 307-309). This added urgency in revising the status quo in the Rhine so that Germany could absorb the strategic resources in the area (Mitcham 2008, 59).

However, Hitler's ambition should have been deterred by the French threat of war supported by other signatories of the Versailles and Locarno Treaties. Articles 42 and 43 of the Versailles Treaty prescribed the demilitarized zone. Article 44 stipulates that a violation of these articles will be considered a "hostile act against the Powers signatory of the present Treaty" (The Avalon Project, "The Versailles Treaty June 28, 1919: Part III"), which meant "equivalent to resort to war" (Emmerson 1977, 20). The five signatories of the Locarno Treaty reconfirmed Article 44 (The Avalon Project, "The Locarno Pact; October 16, 1925”). France was to receive immediate military assistance from Italy, Belgium, and Britain in case of German violation of the terms.

Why did Hitler decide to challenge the regime despite this deterrent threat by France and other signatories? Was there anyone among the policymakers in Berlin who opposed Hitler's judgment based on different rationale? If so, what was it? We now know that it was Hitler and Foreign Minister Konstantin von Neurath who consistently upheld the policy choice of challenging the Rhineland 
regime (TMWC, XVII, 41; Shore 1999, 6; 10; Emmerson 1977, 83). The majority in the German policy circle was very much worried about Hitler's adventurism due to the high likelihood of French retaliation and subsequent defeat of Germany. They reluctantly followed the lead of the Führer because it was particularly "unbearable" for Hitler that a subordinate oppose the decision of a superior openly (TMWC, X, 484). This makes it difficult to find archival evidence that reveals the rationale of the policymakers in the majority who disagreed with Hitler.

However, we have a few documents that show Hitler's reasoning for defying the French deterrent threat. For example, Ambassador Ulrich von Hassell left a detailed report about his meeting with the Führer on February 14 (Shore 1999, 17; DGFP, C/IV, 1142-1144) and on February 20, 1936 (Shore 1999, 12; DGFP, C/IV, 1163-1166). For the opposing views in Berlin on the issue, this study reviews Ambassador Hassell's response to Hitler during the meetings and testimonies of other government officials at the Nuremberg trial.

During Hassell's first interview with Hitler on February 14, 1936, the Führer said he had initially calculated that the right timing for remilitarizing the Rhineland should be around the spring of 1937 when the German army would become substantially stronger. He, however, had changed this view due to t recent international developments and said the challenge against the regime should occur immediately after the ratification of the Franco-Soviet Pact in the French Parliament in late February. Hitler argued that this should be the case even though Germany was still weak and militarily "not yet ready." The following three points were behind his judgment.

First, Germany's adversaries, especially Russia, had embarked on the rearmament program, and they would also have a much powerful army by 1937. Second, as of February 1936, Russia had no intention to have any conflict with the West; Great Britain was "in a bad state militarily" and distracted by other problems (i.e., the crisis in Ethiopia); and France was preoccupied with severe domestic political issues. Third, public opinion in Britain and France was not sympathetic to the Russian Pact. Based on these observations, Hitler concluded that German remilitarization of the Rhineland would not "be answered by military action - though perhaps by economic sanctions" (DGFP, C/IV, 1142). The only variable left was Italy, and Hitler discussed with Hassell the best way to approach Benito Mussolini.

The second meeting took place on February 20, 1936. It started with Hassell's expressing his concerns about possible shifts in Rome's position regarding the Locarno Treaty, given that Great Britain might not intensify sanctions against Italy. Due to the favorable attitude of France toward Italy during the time of 
economic sanction, Rome might choose to act with Paris rather than Berlin. This Italian support should make it easier for France to retaliate against the German challenge against the Rhineland regime. Hitler's response to his concerns can be summarized in the following five points.

First, the Rhineland regime could become "an inviolable institution" as time went by. Second, Italy's recent military success in Ethiopia would harden London's foreign policy against Rome, and sanctions would likely intensify. Third, Mussolini would not seek compromise with Britain after his success in Ethiopia. Fourth, given that the two Fascist states encircled by democratic regimes "tainted by Bolshevism," passivity could never be the right path, and "attack $[\cdots]$ was the better strategy." Fifth, Berlin could address the negative ramification of the German challenge against the regime by simultaneously offering a series of peace treaties. The Führer included the re-establishment of a demilitarized zone on the French/Belgian and German sides, the Three-Power Western air pact, and the long-term non-aggression pact as those possible treaties. These measures would deprive Locarno powers of the possibility to act against the German defiance (DGFP, C/IV, 1165). After hearing this, Hassell warned that "ninety-five percent of the French, and probably most of the British too, would $[\cdots]$ be conscious of the threat involved in the occupation," but the Führer "made no reply" to this (DGFP, C/IV, 1166).

Hassell was hardly the only one in Berlin who was troubled by Hitler's reckless plan. Herr Paul Schmidt, an interpreter at the German Foreign Office, testified at the Nuremberg trial that the fear was felt in the Military circle and the Foreign Office (TMWC, XVII, 41). According to Erich von Manstein, the commander of the Wehrmacht, the German military had tried its best to avoid everything that might be considered a violation of the Treaty of Versailles even by forming a special group exclusively dedicated to this purpose (TMWC, XX, 602). The Führer's decision to dispatch troops came as a complete surprise and shock to military elites. The War Minister Werner von Blomberg and General Werner von Fritsch openly objected to the plan, and Blomberg later urged Hitler to withdraw three battalions that marched across the Rhine to the Western bank as soon as the news of imminent French mobilization of thirteen divisions arrived in Berlin (TMWC, XX, 603-604).

These records in the archive allow us to test the rival and research hypotheses. First, why did Hitler not believe in French deterrent threat? As described above, Hitler's rationale behind moving up the remilitarization plan for about a year was: (1) the year 1937 might not be advantageous for Germany in terms of relative military balance; and (2) Russia, Britain, and France were not prepared to punish the German violation in 1936. The first reason seems to fit well with the prediction 
of the rival hypothesis - Hitler tried to avoid the time zone in which France would become more resolved due to her advantageous position in military strength. In other words, Hitler's challenge against the French deterrence in 1936 was because he did not believe Paris' resolve due to the military balance temporally favoring Berlin.

This explanation, however, fails to pass the smoking gun test. When the Führer discussed the timing of the challenge, he made it clear that Reich was "not yet ready" for a war. This statement implies that it was not precisely because Hitler was confident of German victory in a war against Locarno Powers but because he expected that the adversaries would likely choose a non-action path after the deterrence failure.

More importantly, if the rival hypothesis is valid, Hitler should have had an occupation plan designed for surpassing French and other signatory powers' forces to make his adversaries even more reluctant (or less resolved) to stand firm. Hitler indeed alerted four army corps and 13 infantry divisions when he sent his 19 infantry battalions and 13 artillery units to the demilitarized zone. He also issued specific defensive schemes to three battalions - Aachen, Trier, and Saabrücken - in French retaliation (Emmerson 1977, 97-98; Mitcham 2008, 61-62; Schuker 1986, 304-305). Germany also relocated navy fleets and air force squadrons in preparation for contingencies (Emmerson 1977, 99; TMWC, XXXIV, 645-646). However, this is far from a war plan to overwhelm the Locarno powers. Hitler made every effort to organize the German troops in a way to make them seem non-aggressive and symbolic. Specifically, the Reich forces were purposely not armed with offensive weapons such as tanks and bombers. The carefully designed German dispatch should have made it hard to proclaim that the casus foederis was satisfied for France to take immediate retaliation while receiving military support from the treaty signatories (Emmerson 1977, 96-98). The rival hypothesis, in this regard, fails to survive the hoop test and thus should be rejected.

On the contrary, the research hypothesis predicts that the French deterrent threat was regarded non-credible by Hitler because it was not militarily and politically feasiblefor Paris to follow through. This argument passes the smoking gun test because, as mentioned earlier, expected non-actions of Russia, Britain, Italy, and France were precisely the central basis of Hitler's rationale for renouncing the Rhineland regime.

First, the Führer was aware of the weakness in the Soviet military power. His military attaché in the Soviet Union reported that tremendous work should be done, especially "in the spheres of the armaments industry and transport," for Russia to have some offensive capability. The Russian policy of peace and security 
was the recognition that "they are not yet capable of attack" (DGFP, C/IV, 20).

Second, it seemed evident that Italy would not side with the Stresa powers as long as London tried to thwart Italian success in Ethiopia. Hitler was informed that Italians were most grateful for Germany's non-participation in the British-led economic sanctions. In response, many influential elites in Rome expressed that "the Stresa structure today certainly no longer corresponds to the Italian ideal" (DGFP, C/IV, 959). Mussolini himself declared that "Stresa was dead" and Italy "by no means wished to return to Stresa" (DGFP, C/IV, 1013; 1044). He confirmed that the world would not witness "any diplomatic or political opposition by Italy if Germany were to denounce the Locarno Pact" (DGFP, C/IV, 1161), and Rome "would not participate in any counter-reaction which might be called forth by a German reaction to the ratification [of the Franco-Soviet Pact]" (DGFP, C/IV, 1219).

Third, Hitler learned that the British government was facing domestic opposition to providing military aid to Paris. The political elites in London were annoyed by "French unreliability" due to her disappointing moves during the Mediterranean crisis (DGFP, C/IV, 807). Moreover, the British public suspected that France endeavored to transform the League of Nations into a "one-sided organization" opposing Germany (DGFP, C/IV, 733). The guiding principle of British foreign policy, thus, was far from supporting France to the end but avoiding being "drawn into war with Germany again" (DGFP, C/IV, 906).

Besides, the Führer knew that London was in "a bad state" of military readiness (DGFP, C/IV, 1142). The British Ambassador in Berlin verified this by stating that the British Air Force base was located at "too great a distance to be able, if necessary, to intervene in the event of Britain having to fulfill her obligation to render assistance against Germany" ( $D G F P, \mathrm{C} / \mathrm{IV}, 918)$. It implies that London was not only reluctant to be bound by Locarno obligations but also failed to maintain sufficient power projection capabilities to support France when Paris needed to level up her coercion against Germany or punish Berlin for its attempts to revise the status quo.

Lastly, Hitler anticipated that Paris would face political opposition at home in punishing the German coup in the Rhineland. Indeed, the French government warned Germany many times that there was a solid political consensus in the French government to stand firm against any German provocation (DGFP, C/IV, 1112). Considering French hostility towards Germany due to the former's tremendous loss from World War I (Emmerson 1977, 19) and the fact that Paris ruthlessly had endeavored to cripple Germany during the interwar period (Jackson 2011, 577-610), Germany should not discredit the threat. It was, however, confirmed by French Foreign Minister Pierre Laval that the French public was 
willing to fight only for the "defense of French soil" and opposed "under all circumstances, military action beyond their frontiers" (DGFP, C/IV, 851, 916, 926).

Furthermore, Gottfried Aschmann, Chief of the Foreign Ministry's Press Division, wrote a report attesting to division in French Politics. Politicians in Paris passed the buck to the Army General Staff when it came to countermeasures for possible German challenges in the demilitarized zone. On the other hand, French military leaders were divided into two groups: one that saw no strategic value in the Rhineland regime due to the technological revolution in military motorization. The other believed in the necessity to maintain the zone until France successfully improved her defensive garrisons. Under this disunity in the French government, Aschmann predicted that "one is neither ready nor willing unhesitatingly to go to war over the eventuality of a German reoccupation [underlined in the original text]" (Shore 1999, 6).

All the above-mentioned documentary evidence proves that Hitler was aware of the colossal political and military obstacles that France and other Locarno powers were facing, which should make it infeasible for them to punish the German violation of the treaty. Hitler precisely linked this strategic context to his decision to advance his plan to challenge the status quo by one year. Therefore, the research hypothesis passes the smoking gun test.

The hypothesis based on the feasibility model also survives the hoop test. Suppose it was because of the expected infeasibility of the treaty signatories in following through on their threat. In that case, Germany should have exerted every effort to make it more infeasible, or at least keep it as tricky as it was, for Locarno powers to punish Berlin's defiance. James T. Emmerson explains that Berlin exactly took this path and worked along the line for three weeks prior to the remilitarization of the Rhineland (Emmerson 1977, 84-96). Namely, Hitler himself spelled out his scheme to simultaneously offer comprehensive peace treaties when German troops marched into the Rhineland (DGFP, C/IV, 1165; $D G F P, \mathrm{C} / \mathrm{V}, 18-19)$. As mentioned earlier, Berlin also worked out a precise method to make the challenge a non-flagrant violation (Emmerson 1977, 96-98).

Due to the dearth of archival resources to reveal the strategic thinking of other policymakers in Berlin, it is challenging to test the rival and research hypotheses against each other properly. Nevertheless, according to Hassell's report and testimonies of other government officials at the Nuremberg, they worried about several facts. First, they feared that most French people understood the significance of the Rhineland regime - which should make both interests at stake and audience cost high for Paris. Second, they worried that military balance was not favorable to Berlin (high probability of French victoryin war and possibly low war cost for Paris). And, third, they were afraid that France's political feasibility 
of punishment would be enhanced if Rome switched over its support to Paris. These three pieces of evidence allow the two rival and research hypotheses to pass the hoop test, and none should be rejected.

\section{CONCLUSION}

Table 1 summarizes the result of the comparative analysis of the two cases.

Table 1. Summary of the First Moroccan and the Rhineland Crises

\begin{tabular}{|c|c|c|c|c|c|c|}
\hline \multirow[b]{2}{*}{ Cases } & \multirow{2}{*}{ Variables } & \multicolumn{2}{|c|}{ Feasibility } & \multicolumn{2}{|c|}{ Resolve } & \multirow[b]{2}{*}{$\begin{array}{c}\text { Threat } \\
\text { Credibility }\end{array}$} \\
\hline & & $\begin{array}{c}\text { Power } \\
\text { Projection } \\
\text { Capability } \\
\end{array}$ & $\begin{array}{c}\text { Permissive } \\
\text { Political } \\
\text { Environment }\end{array}$ & $\begin{array}{l}\text { Supported by } \\
\text { the Rational } \\
\text { Calculation }\end{array}$ & $\begin{array}{c}\text { Supported by } \\
\text { the Emotional } \\
\text { Force }\end{array}$ & \\
\hline \multirow{2}{*}{$\begin{array}{c}\text { First } \\
\text { Moroccan } \\
\text { Crisis }\end{array}$} & Delcassé & $\times$ & 0 & - & 0 & $x$ \\
\hline & Rouvier & 0 & 0 & 0 & $x$ & 0 \\
\hline \multirow{2}{*}{$\begin{array}{c}\text { Rhineland } \\
\text { Crisis }\end{array}$} & Hitler & $\times$ & $\times$ & 0 & 0 & $\times$ \\
\hline & $\begin{array}{c}\text { Other } \\
\text { Policymakers }\end{array}$ & $\bigcirc$ & $\bigcirc$ & $\bigcirc$ & 0 & 0 \\
\hline
\end{tabular}

In all cases, the threatened side believed in the absolute resolve of the threatener. In the Moroccan crisis, Delcassé believed that Germany was inherently aggressive and resolved to initiate a war. Rouvier thought Germany would most likely attack France as its strategic position was highly advantageous and its interest at stake was high. During the Rhineland crisis, Hitler and other policymakers in Berlin perceived that France would retaliate against the German attempt to remilitarize the Rhineland because of its strategic importance, high audience cost, and the strong negative sentiment that existed between the two countries. Thus, if we determine threat credibility only in terms of the level of resolve, both German and French threats in 1905 and 1936 should be considered credible. Nonetheless, this makes it difficult to explain the variance in states' strategies in the two cases: French de-escalation for the Moroccan crisis and the German escalation in the Rhineland case.

The feasibility of punishment, thus, should be explicitly included in causal models for deterrence/compellence success. The Costly Signaling perspective would argue that the feasibility dimension is assumed as given or already reflected as the probability of victory or the war cost variables. However, thinking about the feasibility of punishment and calculating the likelihood of victory (or war cost) are very different things for policymakers. As Hitler's reasoning demonstrated, estimating the probability of victory becomes the main topic on 
the table only when the belief solidifies around the notion that the threatener secured enough feasibility to implement the threat. This thinking is a sequential, not a simultaneous move, and thus it is more fruitful to think about these variables separately.

This article demonstrates the importance of the feasibility of punishment in the deterrence and compellence literature. Hence, it advocates the inclusion of the variable into the literature and its further analysis. However, the study of the two cases does not provide sufficient and conclusive evidence to prove the causal model advanced in this study. The empirical tests and analyses only show the shortcomings of excluding the feasibility variable from the literature on the threat strategy. Whether the inclusion of this new variable would bring better explanatory and predictive power that outweighs some loss of parsimony should be tested rigorously and extensively against more cases and statistical data. 


\section{REFERENCES}

Anderson, Eugene Newton. 1930. The First Moroccan Crisis, 1904-1906. Chicago: The University of Chicago Press.

Art, Robert J. 1996. "American Foreign Policy and the Fungibility of Force." Security Studies 5(4), 7-42.

Art, Robert J. and Patrick M. Cronin. 2003. The United States and Coercive Diplomacy. Washington: U.S. Institute of Peace.

Baldwin, David A. 1979. "Power Analysis and World Politics: New Trends Versus Old Tendencies.” World Politics 21(2), 161-94.

Bennett, Andrew. 2010. "Process Tracing and Causal Inference.” In Henry E. Brady and David Collier ed., Rethinking Social Inquiry: Diverse Tools, Shared Standards, Rowman \& Littlefield Publishers, 207-220.

Carlson, Lisa. 1998. "Crisis Escalation: An Empirical Test in the Context of Extended Deterrence.” International Interactions 24(3), 225-53.

Clark, Christopher. 2012. The Sleepwalkers: How Europe Went to War in 1914. New York, HarperCollins Publishers.

Collier, David. 2011. "Understanding Process Tracing.” PS: Political Science and Politics 44(4), 823-30.

Danilovic, Vesna. 2002. When the Stakes Are High. Ann Arbor: University of Michigan Press.

Documents on German Foreign Policy (DGFP), 1918-1945. 1957. Series C, Vols. IV-V. London.

Emmerson, James T. 1977. The Rhineland Crisis. London: Maurice Temple Smith.

Fearon, James D. 1994a. "Domestic Political Audiences and the Escalation of International Disputes.” American Political Science Review88(3), 577-92.

Fearon, James D. 1994b. "Signaling versus the Balance of Power and Interests: An Empirical Test of a Crisis Bargaining Model.” Journal of Conflict Resolution 38(2), 236-69.

Fearon, James D. 1995. "Rationalist Explanations for War." International Organization, 49(3), 395-401.

Fearon, James D. 1997. "Signaling Foreign Policy Interests: Tying Hands versus Sinking Costs.” Journal of Conflict Resolution 41, 68-90.

Fearon, James D. 2002. "Selection Effects and Deterrence." International Interactions 28, 5-29.

Fischer, Fritz. 1975. War of Illusions: German Policies from 1911 to 1914. New York: Norton.

Freedman, Lawrence. 1998. Strategic Coercion: Concepts and Cases. New York: 
Oxford University Press.

George, Alexander L. and Richard Smoke. 1974. Deterrence in American

Foreign Policy. New York: Columbia University Press.

George, Alexander L. and William E. Simons. 1994. The Limits of Coercive Diplomacy. Boulder: Westview.

Harvey, Frank P. 1997. The Future's Back: Nuclear Rivalry, Deterrence Theory, and Crisis Stability after the Cold War. Montreal: McGill-Queen's University Press.

Harvey, Frank P. 1999. "Practicing coercion: Revisiting Successes and Failures Using Boolean Logic and Comparative Methods." Journal of Conflict Resolution 43(6), 840-71.

Hayne, M. B. 1993. The French Foreign Office and the Origins of the First World War 1898-1914. Oxford: Clarendon Press.

Herrmann, David G. 1996. The Arming of Europe and the Making of the First World War. Princeton: Princeton University Press.

Huth, Paul and Bruce Russett. 1988. "Deterrence Failure and Crisis Escalation." International Studies Quarterly 32(1), 29-45.

Huth, Paul and Bruce Russett. 1990. "Testing Deterrence Theory: Rigor Makes a Difference." World Politics 42(4), 466-501.

Huth, Paul and Bruce Russett. 1993. "General Deterrence Between Enduring Rivals: Testing Three Competing Models." American Political Science Review 87(1), 61-73.

Huth, Paul. 1997. "Reputations and Deterrence: A Theoretical and Empirical Assessment." Security Studies 7(1), 72-99.

Huth, Paul. 1999. "Deterrence and International Conflict: Empirical Findings and Theoretical Debates." Annual Review of Political Science 2, 25-48.

Jackson, Peter. 2011. "Politics, Culture, and the Security of France: A Reinterpretation of French Foreign and Security Policy after the First World War". French Historical Studies 34(4), 577-610.

Jervis, Robert. 1979. "Deterrence Theory Revisited." World Politics 31(2), 289-324.

Johnson, Jesse C., Brett Ashley Leeds, and Ahra Wu. 2015. "Capability, Credibility, and Extended General Deterrence." International Interactions 41(2), 309-36.

Kennedy, Paul. 1989. The Rise and Fall of the Great Powers. New York: Vintage Books.

Lebow, Richard Ned. 1987. "Deterrence Failure Revisited." International Security 12(1), 197-213.

Lebow, Richard Ned and Janice Gross Stein. 1990. "Deterrence: The Elusive 
Dependent Variable," World Politics 42(3), 336-369.

Mahoney, James, Erin Kimball, and Kendra L. Koivu. 2009. "The Logic of Historical Explanation in the Social Sciences." Comparative Political Studies 42(1), 114-46.

McDermott, Rose, Anthony C. Lopez, and Peter K. Hatemi. 2017. "Blunt Not the Heart, Enrage It: The Psychology of Revenge and Deterrence.” Texas National Security Review 1(1), 69-88.

McManus, Roseanne W. 2017. Statements of Resolve: Achieving Coercive Credibility in International Conflict. Cambridge: Cambridge University Press.

Ministère des Affaitres Etrangères. Documents diplomatiques français (DDF), 1871-1914. 2e série, 1901-1911. Tome 6. Paris.

Ministère des Affaitres Etrangères. Documents diplomatiques français (DDF), 1932-1939. 1963. Second Series, Vol. 1. Paris.

Mitcham Jr., Samuel W. 2008. The Rise of the Wehrmarcht: The German Armed Forces and World War II. Westport, CT: Praeger Security International. Morgan, Patrick M. 1977. Deterrence: A Conceptual Analysis. Beverly Hills: Sage.

Morgan, Patrick M. 2003. Deterrence Now. Cambridge University Press

Orme, John. 1987. “Deterrence Failures: A Second Look.” International Security 11(4), 96-124.

Pape, Robert A. 1996. Bombing to Win: Air Power and Coercion in War. Ithaca: Cornell University Press.

Popper, Karl R. 1968. The Logic of Scientific Discovery. New York: Harper and Row.

Powell, Robert. 1999. In the Shadow of Power: States and Strategies in International Politics. Princeton: Princeton University Press.

Quackenbush, Stephen L. 2006. "Identifying Opportunity for Conflict: Politically Active Dyads." Conflict Management and Peace Science 23(1), 37-51.

Quackenbush, Stephen L. 2011. "Deterrence Theory: Where Do We Stand?" Review of International Studies 37(2), 741-762.

Schaub, Gary Jr. 1988. "Compellence: Resuscitating the Concept," in Lawrence Freedman ed., Strategic Coercion: Concepts and Cases, 37-60. New York: Oxford University Press.

Schelling, Thomas C. 1960. The Strategy of Conflict. Cambridge: Harvard University Press.

Schelling, Thomas C. 1966. Arms and Influence. New Haven: Yale University Press. 
Schuker, Stephen A. 1986. "France and the Remilitarization of the Rhineland, 1936," French Historical Studies 4(3), 299-339.

Seawright, Jason and John Gerring. 2008. "Case Selection Techniques in Case Study Research:A Menu of Qualitative and Quantitative Options." Political Research Quarterly61(2), 294-308.

Sechser, Todd S. and Mathew Fuhrmann. 2017. Nuclear Weapons and Coercive Diplomacy. Cambridge: Cambridge University Press.

Shore, Zach. 1999. "Hitler, Intelligence and the Decision to Remilitarize the Rhine." Journal of Contemporary History 34(1), 5-18.

Slantchev, Branislav L. 2011. Military Threats: The Costs of Coercion and the Price of Peace. New York: Cambridge University Press.

Sperandei, Maria. 2006. "Bridging Deterrence and Compellence: an Alternative Approach to the Study of Coercive Diplomacy." International Studies Review 8, 253-80.

Trial of the Major War Criminals before the International Military Tribunal. X-XX. 1948. Nuremberg, Germany.

Weinberg, Gerhard L. 1970. The Foreign Policy of Hitler's Germany: Diplomatic Revolution in Europe 1933-36. Chicago: The University of Chicago Press.

Williamson, Samuel R. 1969. The Politics of Grand Strategy: Britain and France Prepare for War, 1904-1914. Cambridge: Harvard University Press.

Yale Law School Lillian Goldman Law Library. 2008. The Avalon Project: Documents in Law, History and Diplomacy. "The Versailles Treaty June 28, 1919: Part III.” Accessed at http://avalon.law.yale.edu/imt/partiii.asp (November 17, 2021); “The Locarno Pact; October 16, 1925." Accessed at http://avalon.law.yale.edu/20th_century/locarno_001.asp (November 17, 2021)

Zagare, Frank C. and D. Marc Kilgour. 2000. Perfect Deterrence. Cambridge: Cambridge University Press. 